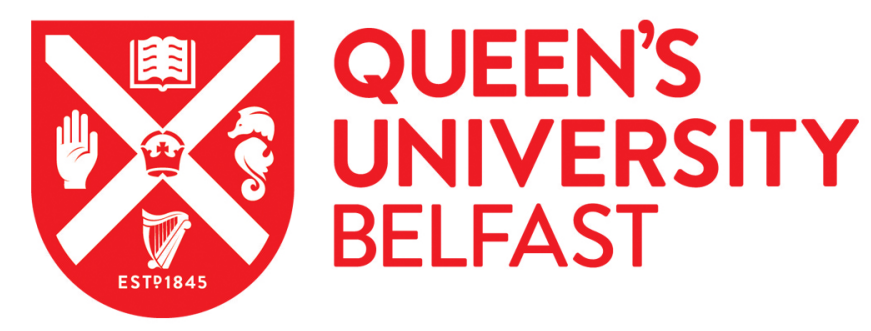

\title{
Optimisation of time/temperature treatment, for heat treated soft wheat flour
}

Neill, G., Magee, T. R. A., \& Al-Muhtaseb, A. H. (2012). Optimisation of time/temperature treatment, for heat treated soft wheat flour. Journal of Food Engineering, 113(3), 422-426.

https://doi.org/10.1016/j.jfoodeng.2012.06.019

Published in:

Journal of Food Engineering

Document Version:

Peer reviewed version

Queen's University Belfast - Research Portal:

Link to publication record in Queen's University Belfast Research Portal

\section{Publisher rights}

This is the author's version of a work that was accepted for publication in Journal of Food Engineering. Changes resulting from the publishing process, such as peer review, editing, corrections, structural formatting, and other quality control mechanisms may not be reflected in this document. Changes may have been made to this work since it was submitted for publication. A definitive version was subsequently published in Journal of Food Engineering, VOL 113, 12/2012

\section{General rights}

Copyright for the publications made accessible via the Queen's University Belfast Research Portal is retained by the author(s) and / or other copyright owners and it is a condition of accessing these publications that users recognise and abide by the legal requirements associated with these rights.

Take down policy

The Research Portal is Queen's institutional repository that provides access to Queen's research output. Every effort has been made to ensure that content in the Research Portal does not infringe any person's rights, or applicable UK laws. If you discover content in the Research Portal that you believe breaches copyright or violates any law, please contact openaccess@qub.ac.uk. 


\section{Accepted Manuscript}

Optimisation of time /temperature treatment, for heat treated soft wheat flour

G. Neill, Ala'a H. Al-Muhtaseb, T.R.A. Magee

PII:

S0260-8774(12)00315-9

DOI:

http://dx.doi.org/10.1016/j.jfoodeng.2012.06.019

Reference:

JFOE 6999

To appear in:

Journal of Food Engineering

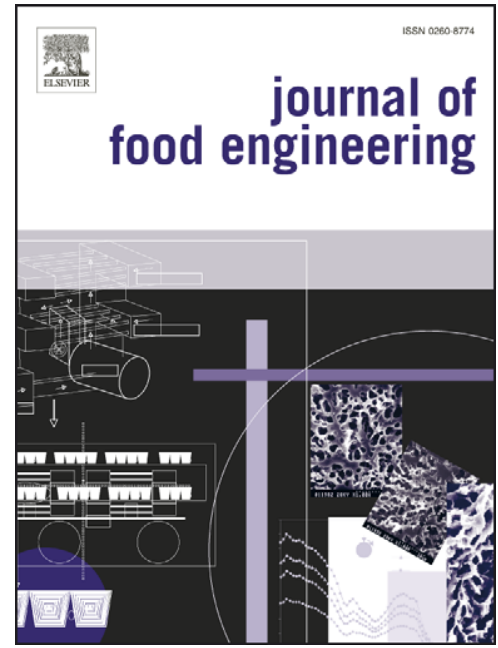

Received Date:

28 February 2012

Revised Date:

8 June 2012

Accepted Date:

27 June 2012

Please cite this article as: Neill, G., Al-Muhtaseb, A.H., Magee, T.R.A., Optimisation of time/temperature treatment, for heat treated soft wheat flour, Journal of Food Engineering (2012), doi: http://dx.doi.org/10.1016/j.jfoodeng. 2012.06.019

This is a PDF file of an unedited manuscript that has been accepted for publication. As a service to our customers we are providing this early version of the manuscript. The manuscript will undergo copyediting, typesetting, and review of the resulting proof before it is published in its final form. Please note that during the production process errors may be discovered which could affect the content, and all legal disclaimers that apply to the journal pertain. 
1

2

3

4

5

6

7

8

9

10

11

12

13

14

15

16

17

18

19

20

21

22

23

Optimisation of time /temperature treatment, for heat treated soft wheat flour

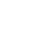

G.Neill ${ }^{\mathrm{a}}$,Ala'a H. Al-Muhtaseb ${ }^{\mathrm{b}^{*}}$, T.R.A. Magee ${ }^{\mathrm{a}}$

4

${ }^{a}$ School of Chemistry and Chemical Engineering, Queens University Belfast, David Keir Building, Stranmillis Road, Belfast, BT9 5AG, UK

${ }^{\mathrm{b}}$ Department of Petroleum and Chemical Engineering, Faculty of Engineering, Sultan

Qaboos University, Oman

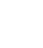

10

11

2

15

\section{*Corresponding Author}

Dr. Ala'a H Al-Muhtaseb

E-mail: muhtaseb@ @qu.edu.om 


\section{Abstract}

25 Chlorination of wheat flour in the EU countries has been replaced in recent years, to some 26 extent, by heat treated flour which is used to produce high ratio cakes. Heat treated flour 27 allows high ratio recipes to be developed which generate products with longer shelf life, finer texture, moist crumb and sweeter taste. The mechanism by which heat treatment improves the flour is not fully understood, but it is known that during the heat treatment process, protein denaturation and partial gelatinization of the starch granules occurs, as well as an increase in

31 batter viscosity. Therefore, it is important to optimize the flour heat treatment process, in 32 order to enhance baking quality. Laboratory preparation of heat treated base wheat flour 33 (culinary, soft, low protein) was carried out in a fluidised bed drier using a range of temperatures and times. The gluten was extracted from the final product and its quality was tested, to obtain objective and comparative information on the extent of protein denaturation. The results indicated that heat treatment of flour decreases gluten extensibility and partial gelatinization of the starch granules occurred. After heat treatment the gluten appeared to retain moisture. The optimum time/temperature for the heat treatment of base flour was

$39120^{\circ} \mathrm{C}$ to $130^{\circ} \mathrm{C}$ for 30 min with moisture content of $\approx 12.5 \%$.

41 Keywords: Heat treated flour; Baking; Bulk density; Gluten extensibility; Gelatinisation, 42 Viscosity. 
49 Heat treated flour can be used in many applications in food processing such as cake, biscuit 50 and wafer flours; beadings, batter flour, coatings; soup, sauces, baby food; thickeners for 51 specialities in industrial applications. Heat treated flour was first cited by Russo and Doe 52 (1970) who patented the process using a temperature range of $100^{\circ} \mathrm{C}$ to $115^{\circ} \mathrm{C}$ for a time of 5360 min. Cauvain et al., (1976) suggested a heat treatment for whole wheat and semolina, 54 which was dried to a moisture content of $6 \%$ and then heated for a specific time/temperature, 55 after which the grain was milled in the normal way. In 1979, Hanamoto and Bean patented a 56 method for producing heat treated flour, where the temperature was maintained at $71^{\circ} \mathrm{C}$ for 4 575 days. Guy and Mair (1993) first heat treated base flour gently to a moisture $<5 \%$ w/w, when the gluten was not extensively denatured. After the initial drying process, the flour 59 needed to be heated to a temperature of $130^{\circ} \mathrm{C}$ to $140^{\circ} \mathrm{C}$ for 30 minutes to achieve the 60 optimum performance. Nakamura et al., (2008) observed an increase in the volume of 61 Kasutera cake by dry heating of wheat flour at $120^{\circ} \mathrm{C}$ for $30 \mathrm{~min}$.

62 By applying heat treatment to base flour and removing the moisture, it is possible to modify

63 its physical, rheological and bacteriological properties. The removal of moisture is an integral 64 part of achieving the overall changes required, but it is important that the flour moisture is 65 adjusted back to $12 \%$ (wet basis), for optimum baking results such as decrease in bulk 66 density and an increase in cake height, which contributes to the overall quality such as 67 appearance and mouth feel. Cake batters made with heat-treated flour have been reported to 68 exhibit higher viscosity compared with batters made with untreated flour (Sahin, 2008). 69 Several studies on the effect of heat treatment on physical and chemical characteristics of 70 wheat flours have been published (Ozawa et al., 2009). Purhagen et al. (2011) studied the use 71 of normal and heat-treated barley flour along with waxy barley starch as anti-staling agents in 
72 laboratory and industrial baking processes. Baked breads with heat-treated barley flour

73 differed from control breads with regard to water content, firmness and amylopectin

74 retrogradation. The addition of barley additives as native- or heat-treated flour or native- and

75 heat-treated waxy starch resulted in increased water contents in the fresh bread as well as

76 increased water retention during storage compared to the control. The rheological behaviour

77 of high ratio cake batters prepared with untreated and heat-treated wheat flours were also

78 studied by Meza et al. (2011). They found that materials prepared with heat-treated flours

79 exhibited greater stability, as indicated by slurry thixotropy and cohesive energy, and the

80 change in apparent viscosity and air content of foams and aerated emulsions on extended

81 mixing. The gel network generated in aerated emulsions prepared with heat-treated flours

82 was significantly stronger than those made with unheated flours. The objectives of this work

83 are to determine optimum time/temperature treatment of base flour to produce heat treated

84 flour by evaluating protein quality, gelatinization temperature, and peak viscosity of the flour,

85 and to evaluate baking height and bulk density of Madeira cake. Heat treated flour is more

86 suitable than base flour for producing high ratio cakes because it improves quality in terms of

87 finer texture and lower bulk density.

\section{2- Materials and Methods}

\subsection{Heat treated flour preparation:}

90 The heat treated flour (batches of 400 grams) was prepared from a commercial base flour in a

91 fluidised bed dryer (Sherwood Scientific Model MK11, UK), using a range of times (5 to 30

92 minutes) and temperatures $\left(80\right.$ to $\left.130^{\circ} \mathrm{C}\right)$, when the moisture content was reduced from

$9312.5 \%$ (wet basis), to moisture of $<8 \%$.(wet basis) The moisture content of the heat treated

94 flour was increased to the original moisture value using a Kenwood mixer (model KM199,

$95 \mathrm{UK})$, when required volume of water was sprayed onto the flour during mixing. Moisture 
96

97

98

99

100

101

102

103

content analyses were carried out in duplicate $( \pm 0.01 \%)$ using a convective oven at $130^{\circ} \mathrm{C}$ for

90 minutes. The temperature was adjusted via the control on the front of the dryer and the velocity was set at maximum (air flow setting 9). The temperature and air velocity were checked using a digital thermometer, (range $-50^{\circ} \mathrm{C}$ to $1300^{\circ} \mathrm{C} \pm 0.3 \% \operatorname{rgd}+1 \%$ ) and a hot wire anemometer, (range 0.4 to $30 \mathrm{~m} / \mathrm{s} \pm 3 \%$ ) before the start of each experiment.

\subsection{Cake batter preparation:}

Madeira cake batter was prepared based on the ingredients and procedures used by Cook, (2002) (Table 1).

1. All the ingredients were allowed to reach $20-21^{0} \mathrm{C}$ before mixing.

2. Dry ingredients were sieved together using a $1 \mathrm{~mm}$ hand sieve.

3. The glycerine, egg and water were placed into the Hobart mixing bowl.

4. The sieved dry ingredients and shortening were added to the Hobart bowl.

5. The ingredients were mixed on speed 1 for $30 \mathrm{~s}$, mixing was continued on speed 2 for $1 \mathrm{~min}$.

6. The batter was then mixed on speed 3 for $7 \mathrm{~min}$.

7. The batter was scaled into lined tins (350 g).

8. The cakes were baked in a conventional oven.

\subsection{Baking equipment and procedure:}

Both heat treated and untreated (base) flour were used to bake the Madeira cakes. A Glenlab convective oven (model OV125L, UK) was used thermostatically controlled to $\pm 0.75^{\circ} \mathrm{C}$ over the temperature range $30^{\circ} \mathrm{C}$ to $250^{\circ} \mathrm{C}$. Before each experiment, the oven was allowed to stabilize at the selected temperature for two minutes. For each experiment, a predetermined weight of batter $(350 \pm 0.1 \mathrm{~g})$ using a Mettler balance (model PJ3000) was placed in the centre of the middle shelf. Each experiment was carried out in duplicate with a control. The 
120

121 Chromel $^{\mathrm{TM}}$ Alumel $^{\mathrm{TM}}$ thermocouple (1mm diameter) using a digital thermometer, accurate to $122 \pm 0.3 \%+1{ }^{0} \mathrm{C}$ in the range $-50^{0} \mathrm{C}$ to $1000^{\circ} \mathrm{C}$.

\section{3}

124

temperature of the oven was set at $175^{\circ} \mathrm{C}$ for 45 minutes and measured with a Type $\mathrm{K}$ After baking, the cake was removed from the oven, and its height was measured along five positions using digital callipers accurate to $0.01 \mathrm{~mm}$. Bulk density was calculated by averaging the results of ten slices of the cake, prepared using a Cookworks food slicer set to $15 \mathrm{~mm}$ thick, and the area measured with digital callipers and weighed on a two decimal place balance. Viscosities were measured on a Brookfield RVDV-11+Pro Cone/Plate viscometer (Cone No51 radius $1.2 \mathrm{~cm}$ ), which was linked to a PC with RHEOCAL32 software installed. (Viscosity accuracy $\pm 1.0 \%$ of full scale range, viscosity repeatability \pm $0.2 \%$ and temperature accuracy $\pm 1{ }^{\circ} \mathrm{C}$ over $100^{\circ} \mathrm{C}$ range). The water bath temperature was set at $25^{\circ} \mathrm{C}$ and allowed to equate before analysis started. The gap between the cone and plate was set electronically to $0.0127 \mathrm{~mm}$ A Brookfield viscosity standard fluid was used to check the calibration before use. All $5 \mathrm{ml}$ samples were checked in triplicate, (accuracy $\pm 2 \%$ S.D.217 mPa.s).

Gluten was extracted from the flour by the following method. Flour was hand washed according to the standard method (Smiling, 1995). This was carried out by kneading the dough sample approximately $10 \mathrm{~min}$ under cold running water until the water was clear and then rested for 30 min before analysis began. The sample was then placed in a test tube and centrifuged for $5 \mathrm{~min}$ at $5000 \mathrm{rpm}$, to remove air bubbles in the sample. After centrifugation, the sample was removed gently from the test tube and $15 \mathrm{~g}$ of gluten placed onto the grooved base. Both the base and top was brushed lightly with paraffin oil to avoid adhesion when removing samples. The top block was pushed firmly into the sample until the two blocks came together, then pressed for $40 \mathrm{~min}$ at $24^{0} \mathrm{C}$ (these parameters used for all samples) to 
144 allow the gluten to relax. The gluten from the press was then removed and moulded into fine 145 strips, which were used for analysis.

146 The gelatinisation temperatures and peak viscosity of heat treated flour were measured. The

147 Brabender viscograph measured the viscosity of flour slurry in a rotational stainless steel 148 bowl $(75 \mathrm{rpm})$ as the temperature increased /decreased by $1.5^{\circ} \mathrm{C}$. A measuring sensor, placed 149 in the slurry is deflected depending on the viscosity of the sample. Results are recorded on a 150 chart and are measured in Brabender Units (BU). The flour slurry was made up of $80 \mathrm{~g} \pm$ $1510.003 \mathrm{~g}$ (as is) of flour and $450 \mathrm{~g} \pm 0.5 \mathrm{~g}$ of purified water. Slurry was placed in the bowl, 152 heated to $92.5^{\circ} \mathrm{C}$ at $1.5^{\circ} \mathrm{C}$ per minute, and held at this temperature for 20 minutes. (Starting 153 temperature for the test is normally $45^{\circ} \mathrm{C}$ ). The start of gelatinisation temperature is the 154 temperature at which viscosity increases by $20 \mathrm{BU}$. Individual starch granules gelatinise over a temperature interval. As the temperature increases more starch granules swell then start to break down and the peak viscosity starts to decrease. The temperature at peak viscosity (peak temp) is defined as the gelatinisation temperature over time. Peak viscosity is the BU at peak temperature.

\section{3- Results and Discussion}

160 The optimum time/temperature profiles for the heat treatment of culinary flour are presented in this section. A commercially heat treated flour was used as a control, and the laboratory heat treated flours, to produce Madeira cakes. The parameters studied were cake height and 163 bulk density, in order to establish the optimum profile (time/temperature) for base heat 164 treated flour. 
167

168

169

170

171

172

173

174

175

176

177

178

179

180

181

182

183

184

\subsection{Baking height:}

Base flour, heat treated at $80^{\circ} \mathrm{C}$, increased slightly in baking height $(3.8 \%)$. As the temperature increased, the baking height also increased to $10.7 \%$ at $130^{\circ} \mathrm{C}$. The results also showed that time in the oven contribute to an increasing baking height. Heights were very similar when the base flour was heat treated at $120{ }^{\circ} \mathrm{C}$ and $130{ }^{\circ} \mathrm{C}$ for 30 minutes. Guy and Mair (1993) and Cauvain (1999) suggested that to achieve optimum improvement, the flour had to be heated gently to reduce moisture $<5 \% \mathrm{w} / \mathrm{w}$ before heating at temperatures between $130^{\circ} \mathrm{C}$ to $140^{\circ} \mathrm{C}$, for 30 minutes. When flour drying temperatures increased above $>140^{\circ} \mathrm{C}$ there were cooked taints in the flour.

Figure (1) shows the baking result for the optimum time/temperature $\left(30 \mathrm{~min}\right.$ at $\left.130^{\circ} \mathrm{C}\right)$. Figure (2) shows the moisture level of the heat treated flour that is required to produce the optimum baking height. From the results, final flour moisture below $4 \%$ gave the best result. Cauvain (1999) suggested that final flour moisture should be less than $8 \%$ and closer to $4 \%$. The monitoring of moisture level could be a guide, when producing commercial heat treated flour, because of the improved quality of the Madeira cake. Figure (3) shows Madeira cakes produced from culinary flour, optimum heat treated and commercially heat treated flour.

The cake baked using culinary flour was similar in cake height to the control sample when removed from the oven, but collapsed when it cooled to room temperature, indicating that the product had no internal texture. The Madeira control cake was the benchmark for all the baking trials, which demonstrated a cake with a good height, a well defined central crack, and a good crust colour. The cake produced from optimum heat treated flour had a less defined central crack and the contour surface was similar to the control but more pitted.

Figure (4) shows bulk density of Madeira cakes made from heat treated base flour, at the different oven temperatures and times. Cakes were produced from base and commercially 
191

192

193

194

195

196

197

198

199

200

201

202

203

204

205

206

207

208

209

210

211

212

213

214

heat treated flour (control). The base flour had a higher bulk density than the control and cakes produced from flour at $130{ }^{\circ} \mathrm{C}$, had also collapsed and therefore were more compacted. At the lower temperatures from $80^{\circ} \mathrm{C}$ to $120^{\circ} \mathrm{C}$ the cakes had not fully developed and therefore had not gained the height of the control, resulting in higher bulk densities. This was not the case for cakes produced from flour at $130^{\circ} \mathrm{C}$ and control; they expanded to their normal height, giving a smaller bulk density, i.e., a more open structure which contributes to a more desirable mouth feel by the consumer.

\subsection{Batter viscosity:}

It is important to understand rheological characteristics of food material, for plant and product design. The quality of cakes such as volume and texture can be attributed to cake batter rheological properties. Figure (5) shows that the untreated, and heat treated flours at $80^{\circ} \mathrm{C}$ and $100^{\circ} \mathrm{C}$ have low viscosity values. Heat treatment of flour denatures most protein at temperatures from $50^{\circ} \mathrm{C}$ to $80^{\circ} \mathrm{C}$ (Slade and Levin, 1995) and reduces their solubility in water. Heating leads to disulphide bond linked aggregates and conformational (Attenburrow et al., 1990) changes affecting mostly gliadins and low molecular weight albumins and globulins (Guerrieri et al., 1996). Falcão-Rodrigues et al., (2005) suggested that the gliadins have a significant role by imparting a higher viscosity. This was also confirmed by Attenburrow et al. (1990), Kokini et al. (1994) and (Kim et al., 2004), who suggested that due to cross-linkage reactions, gluten viscosity increases on heating, because of the swelling and gelatinization of starch granules, which also has a major factor on batter viscosity. A combination of starch swelling, gelatinisation and protein denaturing, resulted in higher viscosities in batters using heat treated flour compared to those using base flour. 
215

216

217

218

219

220

221

222

223

224

225

226

227

228

229

230

231

232

233

234

235

236

237

238

\subsection{Brabender viscograph viscosities:}

In Table (2) the gelatinization temperature for the heat treated base flour is within a narrow range of $57.2^{\circ} \mathrm{C}$ to $57.8^{0} \mathrm{C}$, at two high temperature heat treatments. The base flour, which was not heat treated, had a gelatinization temperature of $58.9^{\circ} \mathrm{C}$. It also shows that the peak viscosity progressively increases as the temperature/ time increases suggesting that a higher number of starch granules have swollen, giving high peak viscosities. The control sample has similar peak viscosity (320 BU). However, the culinary flour had a higher gelatinisation temperature of $58.9^{\circ} \mathrm{C}$ and a peak viscosity of $220 \mathrm{BU}$, suggesting a much lower level of swollen starch granules present. In Figure (6) only one temperature was selected $\left(100^{\circ} \mathrm{C}\right)$ and heat treated through a range of times. This behaviour is repeated again. As the time increases there was an increase in peak viscosity and a change in gelatinization temperature. From the results, heat treatment appears to have increased the ability of the starch granules to absorb more water. To some degree, denatured proteins may have contributed to the level of viscosity and also the mechanical damage to starch at milling. The proteins on the surface of the starch are hydrophilic albumin and globulin and could be modified by chlorine and heat treatment (Barlow et al., 1973). Seguchi (1984) showed that hydrophobicity of starch granules increased with such treatment. Similar increases were observed when flours were heat treated (Johnson et al., 1980). The modification of these proteins may allow the starch granules to absorb more water. The culinary flour had a peak viscosity of 220 BU suggesting that the starch granule surface had no modification and a barrier remained with less ability to absorb water. Johnson et al. (1980) suggested the effects of heat treatment of starch improved baking quality, viscosity being the controlling factor for the final cake volume. 
239

\section{0}

241

242

243

244

\subsection{Gluten extensibilities:}

Gluten extensibility is a measure of the degree of protein denatutation in the flour due to the extent of heat treatment which may affect the viscosity of the cake batter, an important parameter in the quality of the baked product. Increased viscosity leads to an increase in baking height, which can result in a more attractive appearance.

The extensibilities show a decreasing extensibility $(\mathrm{mm})$ possibly due to a reduction in gliadin due to heat treatment. This can be seen in Figures (7), (8) and (9) which represent the extensibility of base flour, heat treated base flour $\left(120^{\circ} \mathrm{C}\right.$ for $\left.30 \mathrm{~min}\right)$ and heat treated base flour $\left(130^{\circ} \mathrm{C}\right.$ for $\left.30 \mathrm{~min}\right)$ glutens. The gluten samples had also lost their cohesion, indicating that there was a reduction in gliadin level. These figures suggest that the heat treated base flour contains more gluten than the non treated base flour. This may be due to the gluten being easier to wash and retains less starch. This is in agreement with results obtained by Ritchie (1985). During hand extraction, the heat treated flour was less cohesive than the culinary gluten. Heat treated gluten broke down in small aggregates of gluten. Flours that were heat treated and then rehydrated to $12 \%$ moisture appear to retain their moisture and give higher gluten weights Table (3). This may be a factor in the migration of moisture during storage of the baked product. These results are based on heat treatment at two time/temperature combinations, but may require a range of time/ temperature treatment and different wheat varieties which may react differently to heat. 
262

263

264

265

266

267

268

269

270

271

272

273

274

275

276

277

278

279

280

281

282

283

284

285

\section{Conclusions:}

On the basis of this work the following conclusions can be drawn.

- Heat treatment of base flour acts as an improver, by increasing Madeira cake height, and bulk density, whereas base flour without heat treatment produces poor high ratio cakes with high bulk density and low height.

- Optimum time/temperature $\left(120^{\circ} \mathrm{C}\right.$ to $130^{\circ} \mathrm{C}$ for $\left.30 \mathrm{~min}\right)$ heat treatment of base flour with moisture $12.5 \%$ can produce good quality Madeira cake.

- Flour heat treatment affects viscosity which has an important role in final cake quality. Batter viscosity increase may be due to denatured gluten and partial starch granule gelatinization.

- Flour heat treatment decreased gluten extensibility and reduced cohesion which has positive effects on baking quality as the gluten appears to retain its moisture whereas base flour gluten retained its extensibility and cohesion. 
286

287

288

289

290

291

292

293

294

295

296

297

298

299

300

301

302

303

304

305

306

307

308

309

310

311

312

313

314

315

316

317

318

\section{References:}

Attenburrow, G., Barnes, D.J., Davies, A.P., \& Ingman, S.J. (1990). Rheology properties of wheat gluten. Journal of Cereal Science, 12, 1-14.

Barlow, K.K., Butterose, M.S., \& Vesk, D.H. (1973). The nature of the starch protein interface in wheat endosperm. Cereal Chemistry, 50, 443-446.

Cauvain, S.P., Hodge, G., Muir, D.M., \& Dodds, N.J. (1976). Treatment of grain. U.S.: A23B 4/04.

Cauvain, S.P. (1999). Alternative to Chlorination for cake flour production. AACC.Convention.

Cook, S. (2002). Factors affecting the production of cakes from heat-treated cake flour. Review 20 Supplement 1 edn. Campden \& Chorleywood Food Research Association Group.

Falcao-Rodrigues, M.M., Moldao-Martins, M., \& Beirao-Da-Costa, M.L. (2005). Thermal properties of gluten proteins of two soft wheat varieties. Food Chemistry, 93, 459-465.

Guy, R.C.E. and Mair, C., (1993). The improvement of wheat flours for use in high-ratio cake products. Heat moisture treatment. pp1-18 Unpublished

Guerrieri, N., Alberti, E., Lavelli, V. and Cerletti, P., (1996). Use of spectroscopic and fluorescence techniques to access heat induced molecular modifications of gluten. Cereal Chemistry, 73, 368-374.

Hanamoto, M., \& Bean, M. (1979). Process for improving baking properties of unbleached cake flours. US: A21D6/00.

Johnson, A.C., Hoseney, R.C., \& Ghiasi, K. (1980). Chlorine treatment of cake flours. Cereal Chemistry, 57, 94-96.

Kim, W., Choi, S.G., Kerr, W.L., Johnson, J.M., \& Gains, C.S. (2004). Effect of heating temperature on particle size distribution in hard and soft wheat. Journal of Cereal Science, 40, 9-16.

Kokini, J.L., Cecero, A.M., Madeka, H., \& Graff, D. (1994). The development of state diagrams for cereal proteins. Trends in Food Science \& Technology, 5, 281-288.

Meza, B., Chesterton, A., Verdini, R., Rubiolo, A., Sadd, P., Moggridge, G., \& Wilson, D. (2011). Rheological characterisation of cake batters generated by planetary mixing: Comparison between untreated and heat-treated wheat flours. Journal of Food Engineering $104,592-602$.

Nakamura,C.,Yoshiki, K., \& Seguchi, M. (2008). Increased volume of Kasutera cake by dry heating of wheat flour. Food Science and Technology Research 14, 431-436. 
Ozawa, M., Kato, Y., \& Seguchi, M. (2009). Investigation of dry-heated hard and soft wheat flour. Starch-Stärke, 61, 398-406.

Purhagen, J.K., Sjöö, M.E., \& Eliasson, A. (2011). The use of normal and heat-treated barley flour and waxy barley starch as anti-staling agents in laboratory and industrial baking processes. Journal of Food Engineering, 104, 414-421.

Russo, J.V., \& Doe, C.A., (1970). Heat treatment of flour as an alternative to chlorination. Journal of Food Technology, 5, 363-374.

Ritchie, M.F. (1985). Studies of methodology for fraction and reconstitution of wheat flours. Journal of Cereal Science, 3, 221-230.

Sahin, S. (2008). Cake batter rheology. S.G. Sumnu, S. Sahin (Eds.), Food engineering aspects of baking sweet goods, CSR Press, Boca Raton, Florida, USA.

Seguchi, M. (1984). Oil binding ability of heat treated wheat starch. Cereal Chemistry, 61, 248-250.

Slade, L., \& Levin, H. (1995). Glass transition and water food structure interactions. Advances in Food and Nutrition Research, 38, 103-269.

Smiling, J., (1995). The measurement of dough and gluten extensibility using SMS/Kieffer Rig and the TA.XT2 Texture Analyser. In: Stable Micro Systems Ltd, pp. 1-20. 


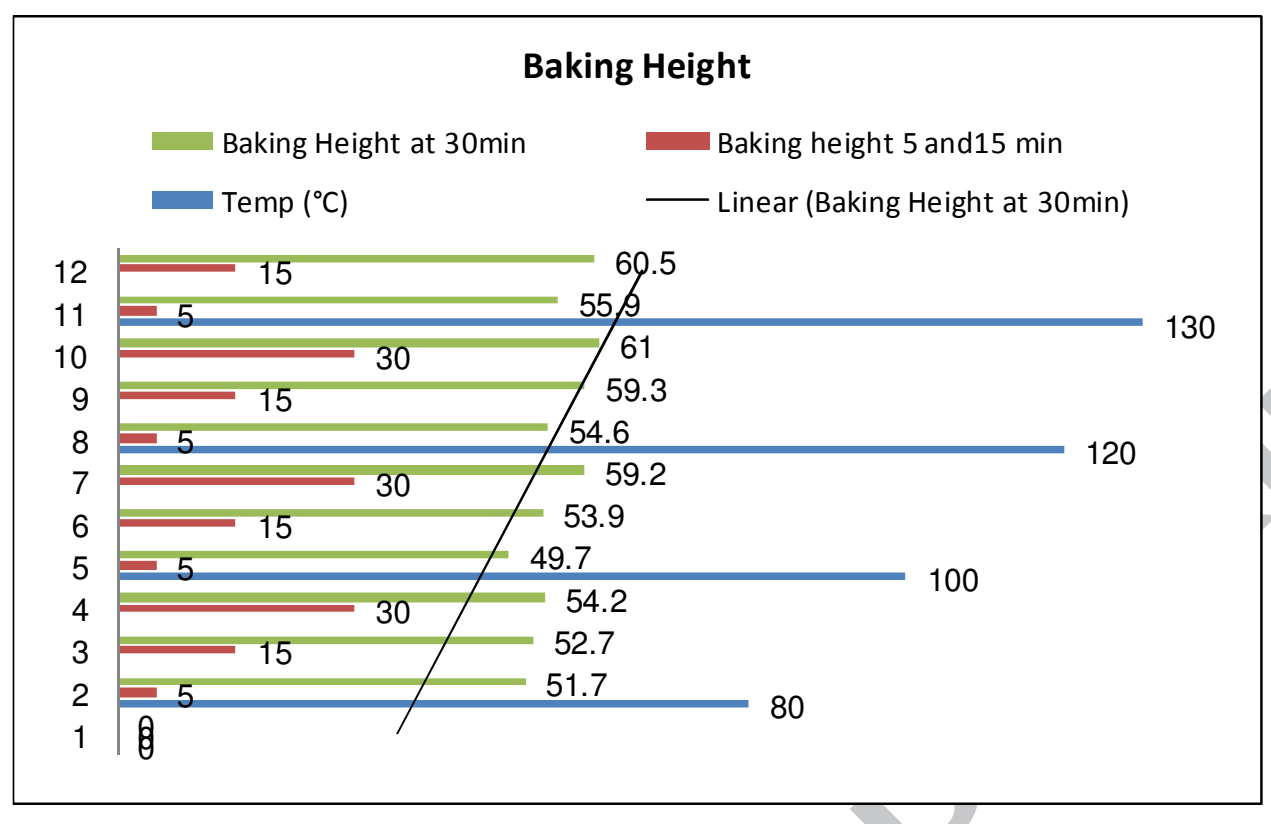

338 Figure 1: Effect of heat treatment on cake height made from flours produced at different 339 temperatures and times. 


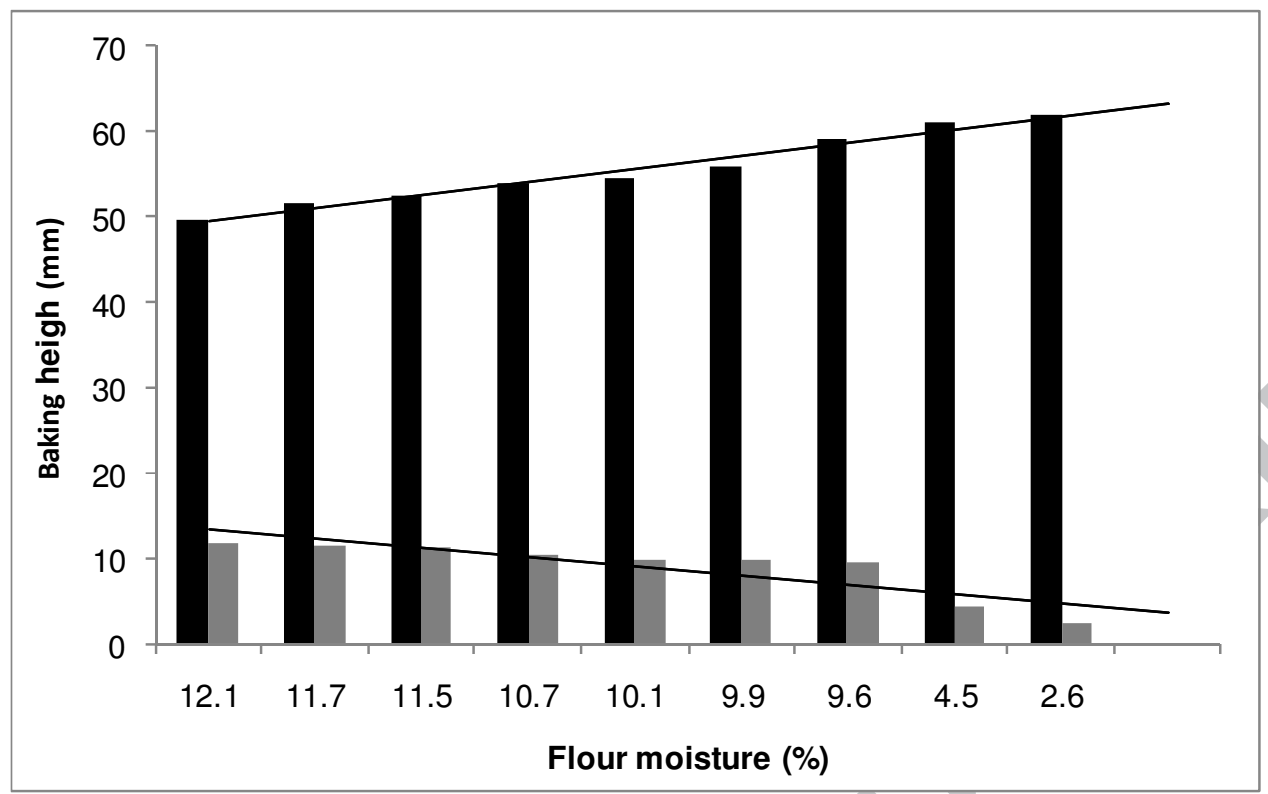

Figure 2: Moisture level of the heat treated flour required to produce the optimum baking 350 height. Shaded bars represent moisture content; black bars are equivalent baking height. 

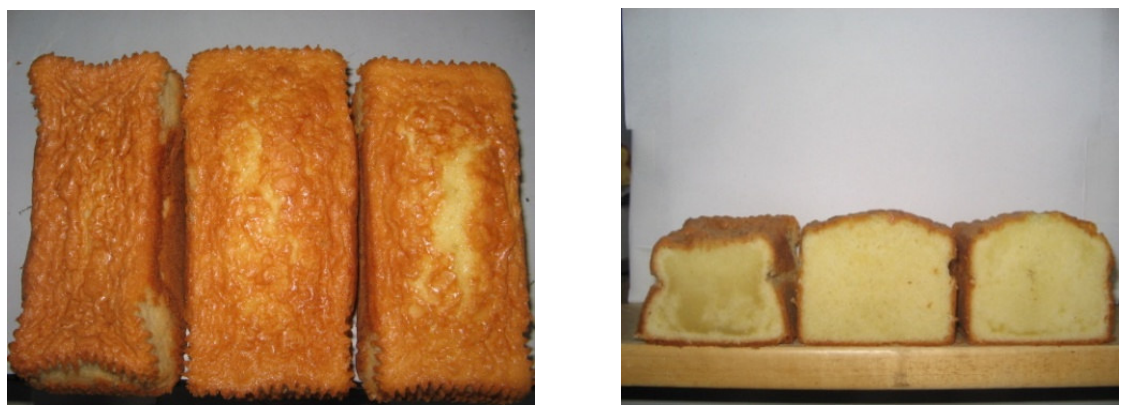

363

364 Figure 3. Madeira cake produced from ( $\mathrm{L}$ to $\mathrm{R}$ ) untreated culinary flour, optimum HT flour $365 \quad\left(130^{\circ} \mathrm{C}\right)$ and from commercially HT flour.

366

367

368

369

370

371

372

373

374

375

376 


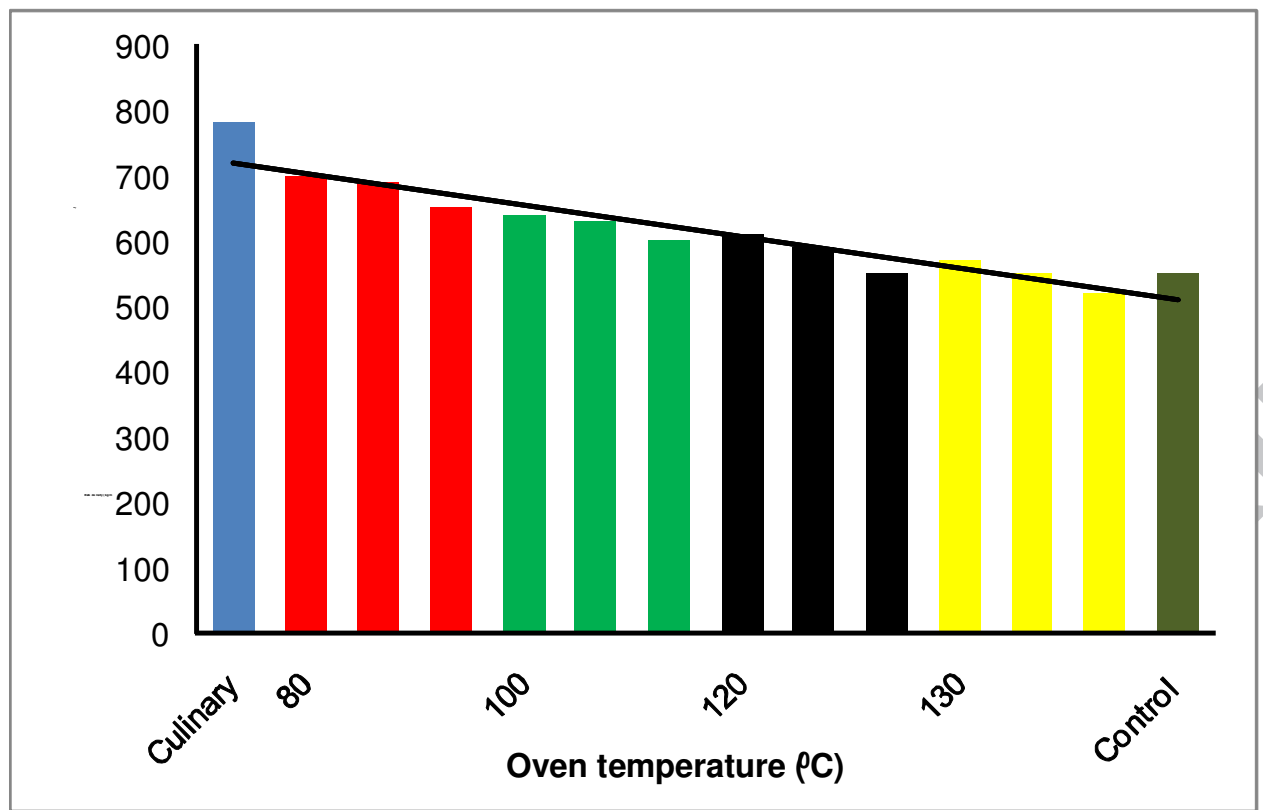

377

Figure 4: Madeira cake bulk densities, baked for $30 \mathrm{~min}$.

379

380

381

382

383

384

385

386

387

388

389 


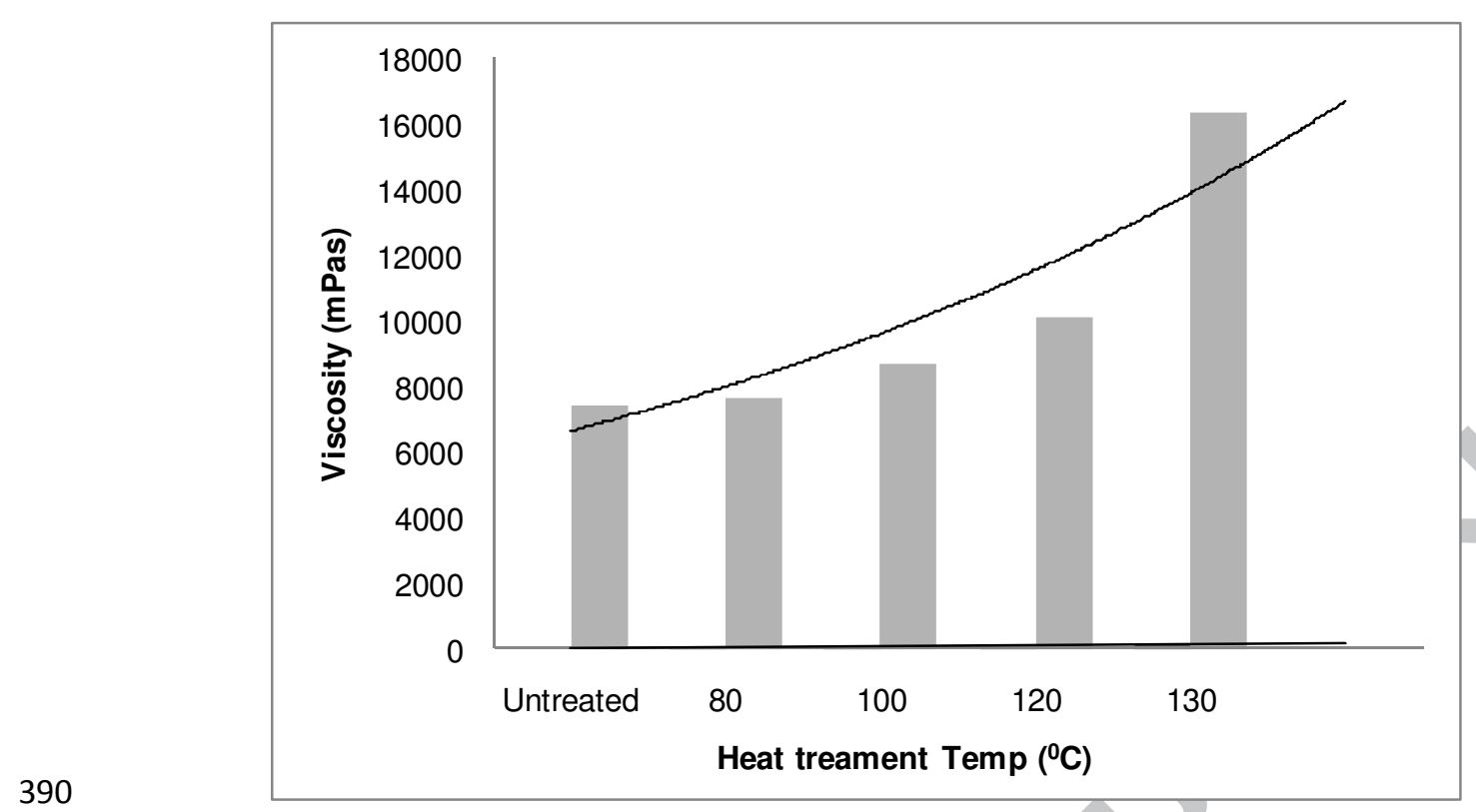

391 Figure 5: Culinary heat treated flour viscosities (processed in a fluidised bed for $30 \mathrm{~min}$,

392 flour moisture rehydrated to $12 \%$ ).

393

394

395

396

397

398

399

400

401

402

403

404 


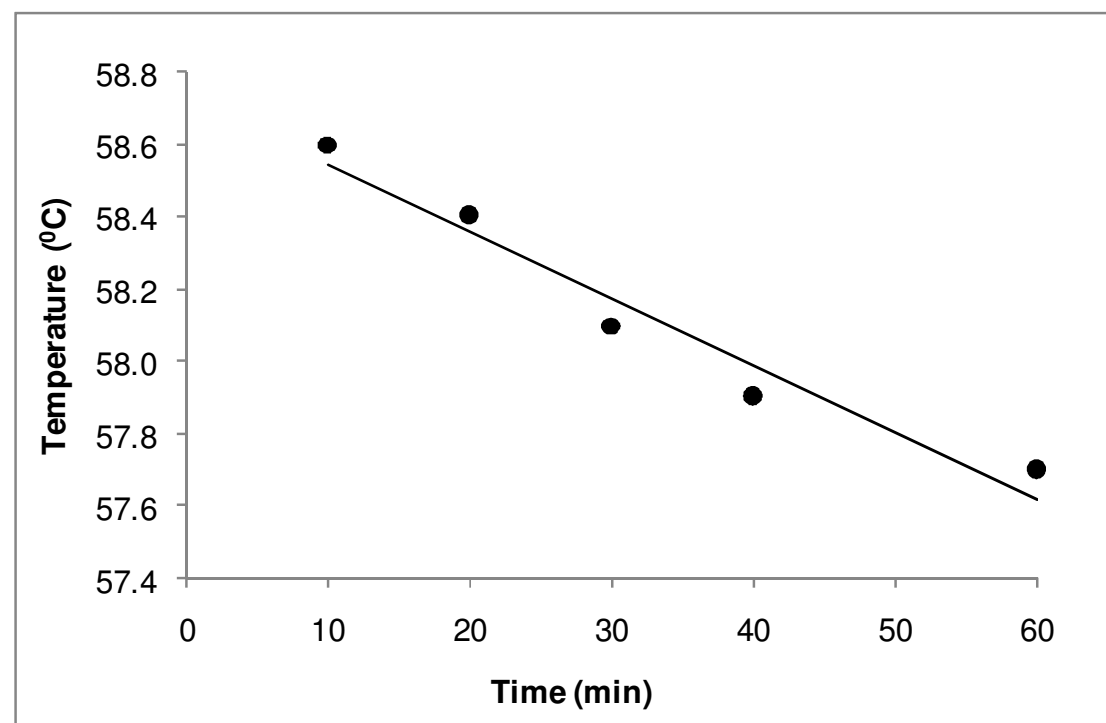

406 Figure 6: Gelatinization temperature.

407

408

409

410

411

412

413

414

415

416

417 


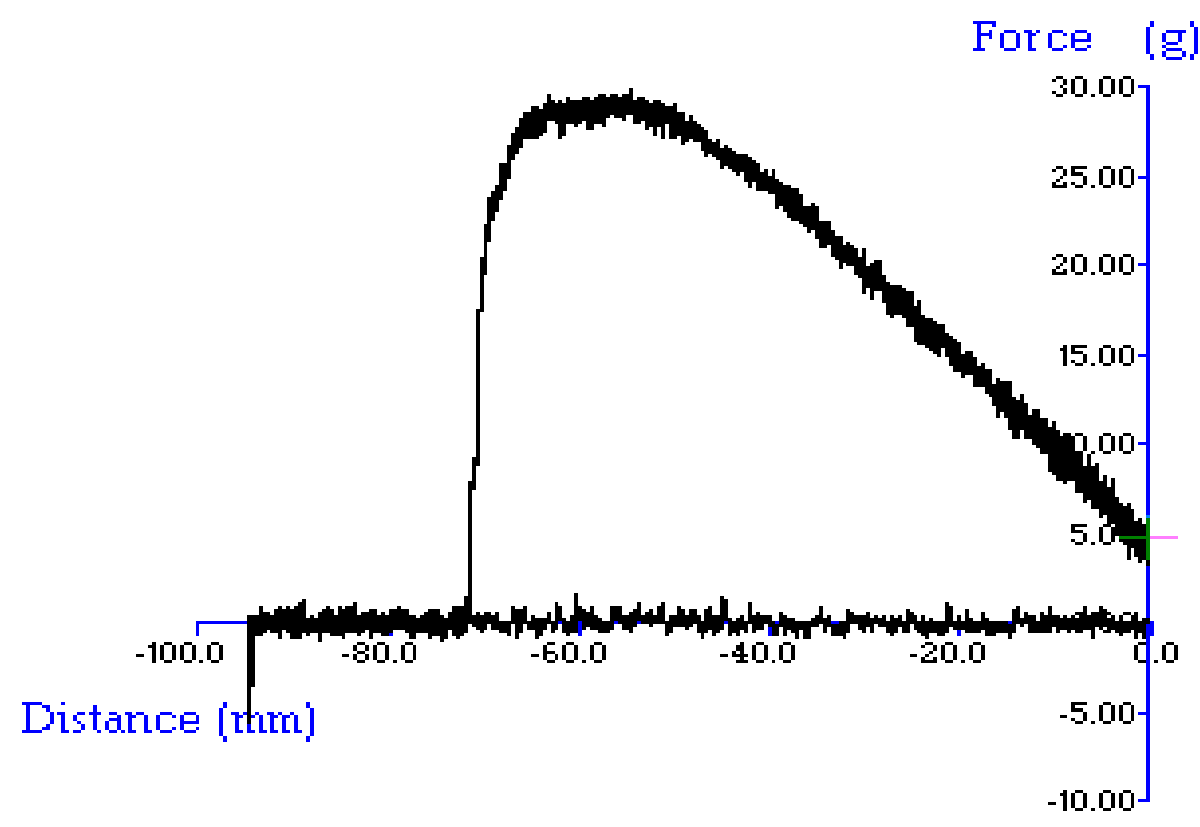

418

419 Figure 7: Extensograph base flour.

420

421

422

423

424

425

426

427

428

429

430

431 


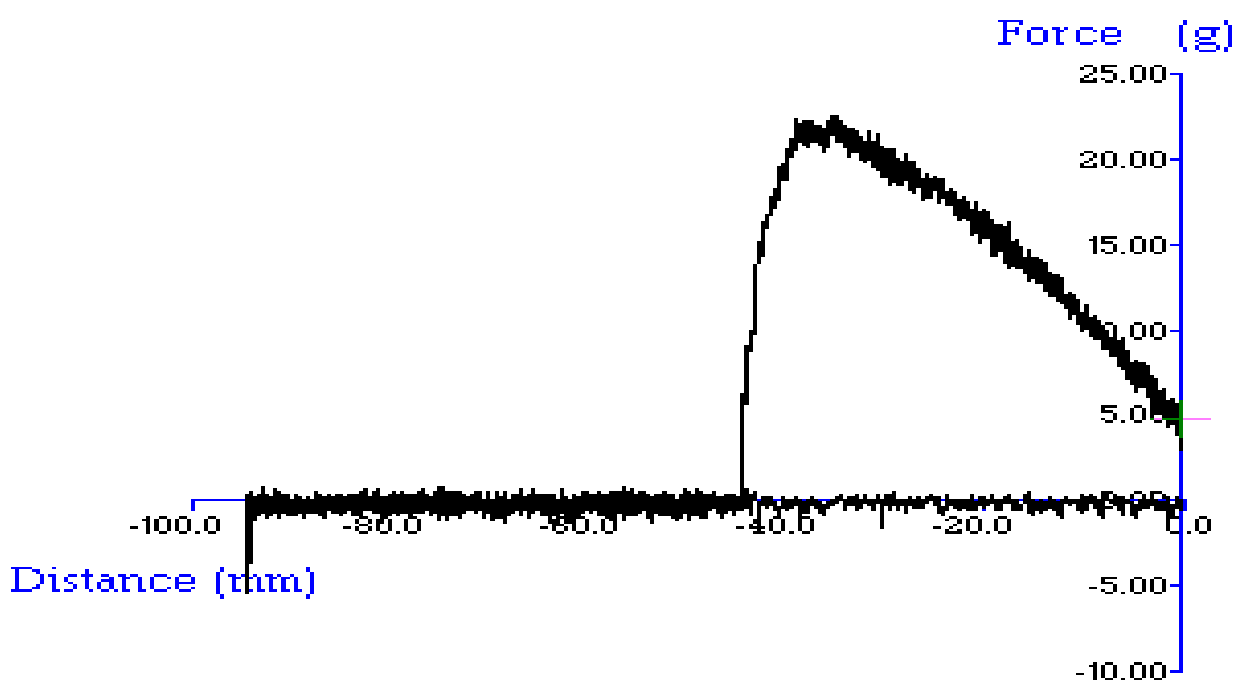

435

436 Figure 8: Effect of base flour heat treated $\left(120^{\circ} \mathrm{C}\right.$ for $\left.30 \mathrm{~min}\right)$.

437

438

439

440

441

442

443

444

445 


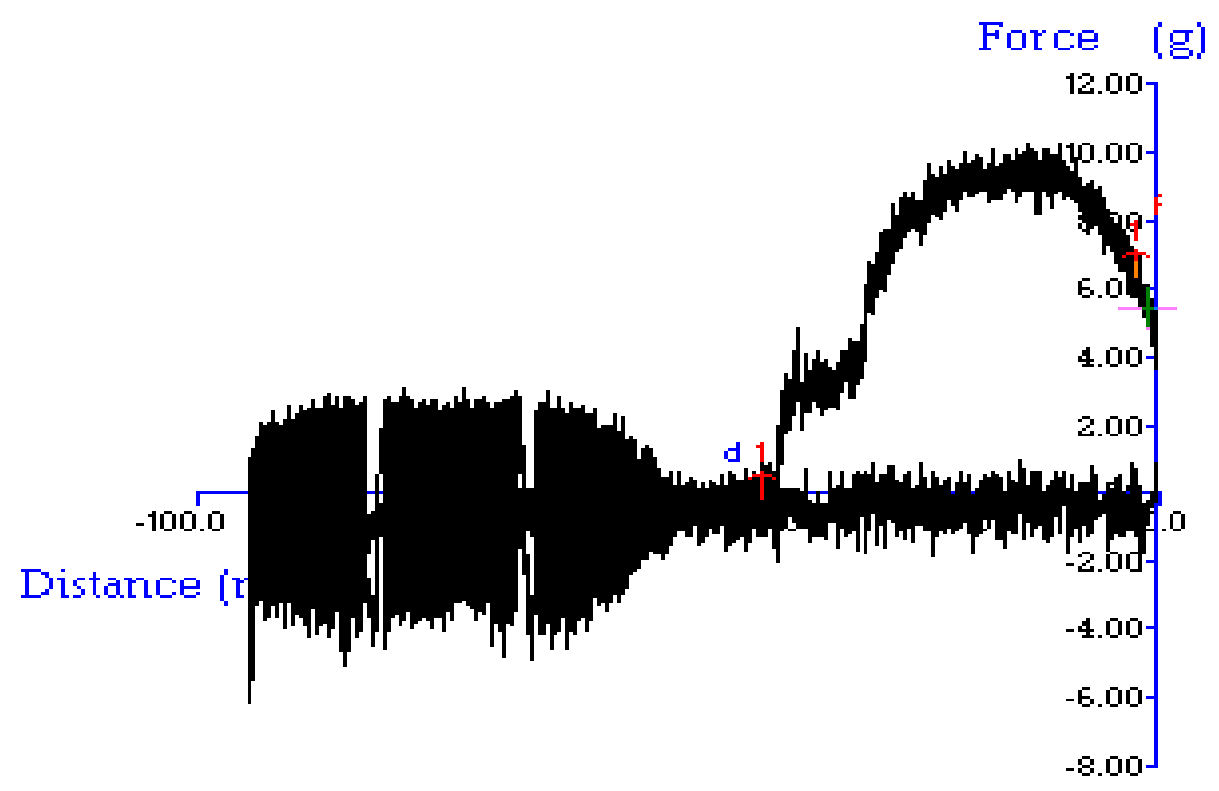

446

$447 \quad$ Figure 9: Effect of base flour heat treated $\left(130^{\circ} \mathrm{C}\right.$ for $\left.30 \mathrm{~min}\right)$.

448

449

450

451

452

453

454

455

456

457

458

459

460

461 
462 Table 1: Madeira cake recipe.

\begin{tabular}{cc}
\hline Flour (Culinary) & $200 \mathrm{~g}$ \\
Skimmed Milk Powder & $14 \mathrm{~g}$ \\
Salt & $5 \mathrm{~g}$ \\
Baking Powder & $8 \mathrm{~g}$ \\
Castor Sugar & $230 \mathrm{~g}$ \\
Water & $140 \mathrm{~g}$ \\
Eggs & $160 \mathrm{~g}$ \\
Glycerine & $16 \mathrm{~g}$ \\
Shortening & $120 \mathrm{~g}$ \\
\hline
\end{tabular}

463

464

465

466

467

468

469

470

471

472

473

474

475

476

477 
Table 2: Flour analysis for treated, untreated and control flours.

\begin{tabular}{lcccc}
\hline Prepared Flour & Moisture\% & Protein \% & $\begin{array}{c}\text { Peak } \\
\text { Viscosity }\end{array}$ & Gelatinisation Temp ( C) \\
& & \multicolumn{3}{c}{ BU } \\
\hline 10 min at $120^{\circ} \mathrm{C}$ & 11.0 & 9.5 & 321 & 57.5 \\
30 min at $120^{\circ} \mathrm{C}$ & 10.8 & 9.6 & 326 & 57.8 \\
60 min at $120^{\circ} \mathrm{C}$ & 10.6 & 9.9 & 371 & 57.4 \\
10 min at $130^{\circ} \mathrm{C}$ & 11.5 & 9.5 & 323 & 57.3 \\
30 min at $130^{\circ} \mathrm{C}$ & 9.2 & 9.7 & 366 & 57.4 \\
60 min at $130^{\circ} \mathrm{C}$ & 8.9 & 9.8 & 491 & 57.2 \\
Control & 12.2 & 9.4 & 320 & 57.8 \\
Base & 13.1 & 9.5 & 220 & 58.9 \\
\hline
\end{tabular}

479

Table 3: Gluten extracted from culinary and heat treated culinary flour (optimum temp $130^{\circ} \mathrm{C}$ for $\left.30 \mathrm{~min}\right)$.

485

486

487

Wet wt

Dry wt

Heat treated Culinary

488

\begin{tabular}{llll}
$3.8 \mathrm{~g}$ & $2.7 \mathrm{~g}$ & $5.6 \mathrm{~g}$ & $3.7 \mathrm{~g}$ \\
$3.5 \mathrm{~g}$ & $2.6 \mathrm{~g}$ & $5.3 \mathrm{~g}$ & $3.5 \mathrm{~g}$ \\
\hline
\end{tabular}

489

490

491

492

493 
496

497 Research Highlights:

498 - Heat treatment of flour improved cake quality such as baking height and volume.

499 - Heat treatment of flour decreases gluten extensibility.

500 - Optimum time/temperature was $120^{\circ} \mathrm{C}-130^{\circ} \mathrm{C}$ for $30 \mathrm{~min}$ with moisture content of

501 $12.5 \%$

502

503

504

505

506

507

508 